\title{
Methodological Approaches of Formation of Evaluative Indicators of Quality of Life
}

Fakhrutdinova L.R.

Kazan Federal University, Institute of Management, Economics and Finance, Kazan, 420008, Russia

Eidelman B.M.

Kazan Federal University, Institute of Management, Economics and Finance, Kazan, 420008, Russia

Rozhko M.V.

Kazan Federal University, Institute of Management, Economics and Finance, Kazan, 420008, Russia

Pratchenko O.V.

Kazan Federal University, Institute of Language, 420008, Kazan, Russia

\section{Doi:10.5901/mjss.2014.v5n24p251}

\begin{abstract}
The article deals with methodological approaches for the essence of quality of life. More precise definition of conceptual framework and definition of the notion of quality of life. The components of quality if life, such as, for example, the level of education, social integration and social consensus, health, life time, security assurance, etc., are described. It is shown that the paradigm of human life and activities which is understood as continuous interaction of individual with his inner and outer world in order to sustain his existence, to pursue abilities and opportunities of a person, is in the basis of the notion of quality of life. Evaluative indicators of quality of life are given. Economic development and quality of life mutually reinforce each other. Actually, they are the elements of one paradigm. Quality of life is the instrument of economic transformations and structural changes.
\end{abstract}

Keywords. Quality of life, economic growth, Human Development Index.

\section{Introduction}

Today the Russian economy has an urgent need for an immediate and deep profound social maneuver towards a particular person, change of conditions of his existence, guarantee of a decent standard of living and opportunities for social and professional development.

The paradigm of the quality of life comes from the fact that social groups with significant qualification and employment potential, high social activity and mobility, the ability to adapt legally to established conditions and to implement effective models of its activities, are the engine of economic dynamics. To create conditions to stimulate mobilization and the economic efficiency of these groups, should be the focus of reforms $[1,2]$.

Economic development and quality of life mutually reinforce each other. In fact, they are members of the same paradigm. Quality of life is a tool of economic reforms and structural changes.

Quality of life is defined as a set of social values that characterize creative activities, satisfaction of needs and human development, people's satisfaction with life, social relations and the environment. Thus, the quality of life is a whole complex of characteristics of life of a person, or a group of people, or all population in general, that determine optimal course of life at a particular time and under certain conditions and that assure adequacy of its parameters to the main human activities and needs [3,4,5].

Quality of life as an integral characteristic of the climate of society and its individuals reflects the condition and trends of development of educational and health services, the pension and social security sphere, the contents of savings strategies of economic agents. The level of development of labor potential is one of the key factors determining the parameters of quality of life of population [6]. Development of market institutions, on the one hand, provided a variety of forms of employment, labor mobility and the effect of price signals in sphere of wages, on the other hand, the gap 
between the quality of education and increasing requirements to the scope of knowledge and professional skills of graduates increased, the aging of the staff of enterprises of the real economy sector is continues, differentiation between regional segments of the national labor market is increasing $[7,8]$.

Currently, there is certain fragmentation in the study of problems of quality of life. The changing socio-economic situation constantly enriches the subject of study and requires generalization of new economic phenomena and processes that affect the quality of life of population[9,10].

\section{Methodology}

Methodological approach to the process of monitoring of quality of life, that reflects the cumulative result of the economic system performance and its accumulated potential consists, firstly, in a sequential study of indicators of the quality of life of population in the statistical sense (the description of the level, structure, and ratio of elements), secondly, in the evolutionary movement (development and change in the interconnection, the form of evolutionary and cyclical motion, the determination of internal patterns and trends), and, finally, thirdly, in the forecast of the development (self-preservation and self-development) of life under different conditions of socio-economic environment [11].

The paradigm of human life, which is defined as the continuous interaction of individual with his internal and external world in order to maintain his existence, to implement human capacities and capabilities, is in the basis of the idea of the quality of life $[12,13]$.

Internal components are determined by personal characteristics, psychological, spiritual, creative qualities of a person.

External components of quality of life are the complex of material, environmental, communication, infrastructural, social and safety conditions of the international, national and regional levels.

Thus, formally the quality of life is a set of characteristics that define the dynamics and stability of human development, the conservation of previously established elements of human potential and the formation of its adaptation elements to the environment.

At the macro level, the objective reality of market development, globalization and internationalization of world economic relations requires the scientific and methodological basis and justification of quantitative and qualitative determination of the human factor.

The peculiarity of approach to the selection and scope of the set of indicators of quality of life consists in the formation of a coherent hierarchical system as a unity of objective (measurable) and subjective (unmeasurable) parameters that characterize the quality of life of the population of the whole country, region, city, etc., as well as the quality of life of an individual member of society (family, group of people) [14].

The European Union countries have already accumulated the experience and theoretical developments in the following spheres:

- human development assessment problems (Human Development Index - HDI, by the program of United Nations development);

- Measurement and evaluation of population welfare (Quality of life satisfaction index $-\mathrm{LCl}$, developed by the international and European organizations: World bank, European Foundation for Quality Management EFQM, International Foundation for Customer Focus - IFCF);

- the development of quality standards of ISO 9000, SA 8000 social standard and other standards of the next generation, where there are norms of rational structure of industrial relations, the humanization of the production process and the influence on human factor;

- the main provisions of the modern conception of improvement of the quality of working life on the basis of democratization and humanization of the labor process and labor relations in the context of social partnership and satisfaction from the achievements of labor as a result of self-realization and self-expression of an employee.

$\mathrm{HDI}$ has four paradigms and is measured by three indicators. The most important paradigms of human development are the following: productivity as a result of effective activities aimed at increase of income and economic growth; equality which is understood as equality of opportunity in implementation of abilities and Fruition (the use of benefits); stability which allows to provide access to the achievements of civilization for current, as well as for future generations; empowerment, suggesting that the development is carried out not only in the interests of the people, but also thanks to their efforts;

Enhancement of abilities suggests that the development is carried out not only in the interests of people, but also thanks to their efforts. 
There are three main indicators among the leading indicators that determine the Human Development Index: life expectancy; level of education; real gross domestic product per capita. Taken together, they represent three main qualities: healthy lifestyle, the level of knowledge, decent social standard of living $[15,16]$.

However, it was recognized that just one index is not able to reflect such a complex notion as human potential and therefore afterwards it was supplemented and improved, primarily due to the disaggregation of the whole population into social, regional or ethnic groups, into groups by gender (men and women), by income distribution level, etc. This smoothed national discrepancies when comparing HDI of different countries.

Components of the main index - especially the methodology of calculation of education and income level - were also modified. Thus, from 1994 the level of income - the average gross domestic product per capita - became to be adjusted for purchasing power parity of dollar (PPP).

A new way of combining HDI components is one of its innovations. Each indicator is described by separate items: life time - by years of life, education - by years of education, income - by purchasing power, the adult literacy - by percentage. In order to be able to use these indicators in the unified system, we use the 0-1 scale, where 0 is the minimum, and 1 is the maximum.

In this case, according to the new method the minimum values are formed historically, for about 30 years. Maximum values are calculated for 30 years ahead. Researches in the field of demography and medicine show that in the next 30 years life expectancy will be about 85 years.

In establishing the new minimum and maximum standards of HDI indicators there is a large discrepancy between the minimum values (25 years of life expectancy instead of 42 years, $0 \%$ of adult literacy instead of $12 \%$ ) and maximum values (85 years of life expectancy instead of 78.6 years, 15 years of education instead of 12.3 years).

The established minimum and maximum values for HDI are the following: life expectancy (years); adult literacy rate (\%); average number of years of education; income (real GDP per capita in the power of dollar).

When socio-economic conditions change worldwide, the boundaries and scope of the minimum and maximum values of the components of $\mathrm{HDI}$, as well as the methodology of calculation can change as well.

\section{Results}

In order to determine the role of the state in the international community it is necessary to determine the social standard of living of people, or, in other words, their well-being. In order to measure the standard of living, it is necessary to determine the indicators it is defined by. Here are some of them: income, purchasing power, wealth or indicators that define the quality of life, such as level of education, social integration and social consensus, health, lifetime, security, etc. in reality, many welfare indicators can be used in as a scale for measuring the standard of life of individual.

Besides, the following indicators are also considered as indicators of welfare: average income, average costs, the average number of calories consumed, quality of food, dependency ratio on households, access to health care system services, location and quality of housing, the distance between medical aid centers, the number of years of school education, the distance between water and gasoline supply points, quality of water sources, human rights, the degree of equality of opportunity between men and women, social participation, social exclusion of individual from society and social dependence, heated housing, literacy, life expectancy.

The welfare indicators that are usually used in practice can be divided into four groups: indicators of income; combined indicators including indicators of income and non-income indicators; indicators of social participation; subjective indicators.

The most commonly used indicators to assess the standard of life are the indicators of income based on available data of revenues and expenditures of population. For example, the standard of living of the individual $A$ is higher than the standard of living of the individual $B$, because his income and the amount of food consumed is higher than that of the individual $\mathrm{B}$. Measurement of welfare by using the indicators of consumption expenditures can often be found in multipurpose surveys on poverty conducted by the World Bank in a number of countries.

The statistical data on income, literacy, health, nutrition, state housing, water supply and sanitation is used to calculate the combined indicators. It is difficult to compare this data, so combined indexes are created, and this allows to present the standard of well-being in the form of a summary indicator. Such indicators are rarely used to measure poverty in a particular country, although such use is quite acceptable. Such indicators are mainly developed to compare the standard of living of population in different countries.

The third way of measuring the well-being, the indicator of social participation, received great popularity among sociologists, considers the well-being, at least, partly, as a function of social integration. In this case the ability of a certain family to follow the accepted in the society traditions, such as food patterns, giving and taking the gifts, participation in 
national holidays, regular consumption of certain products, etc., is the indicator of the standard of its life. For the country it is difficult to calculate this indicator, as far as the whole complex of special surveys is necessary to determine the national welfare.

The method of subjective indicators is the following: individual identifies who is considered to be poor and what is the standard of living of the poor. Having made such conclusion, individual should describe his own standard of living and to compare it with the described level of poverty.

\section{Discussion}

Indicators of living standards, as well as the category of living standards, reflect population welfare, consumption of goods and services, socio-demographic condition of the society. Quality of life is determined not only by consumption, but also by job satisfaction, living conditions, opportunities for human development, environment, etc.

One of the possible variants of the system of quality indicators was proposed by V.T. Smirnov who thinks that economic and political freedoms create conditions for the formation of various life orientation and assessments of quality of life; he presents the system of indicators in three spheres: spirituality, social status and material wealth. In each sphere there are several indicators that, in our opinion, do not always refer to the specified sphere. For example, a health indicator is related to the sphere of material prosperity and well-being. We believe that it is an independent sphere of social security (medical) services.

The following indicators can be health indicators: dynamics of the overall fertility and mortality, fertility and health of the newborn; infant mortality; number of newborn babies with birth congenital malformations; overall morbidity of population (respiratory diseases, cardiovascular diseases); life expectancy of present of future life, etc.

V.Bokov and P.Mstislavsky were the first who attempted to introduce a foreign method for determining the living standards of population into the Russian reality. They propose to use the following groups of indicators:

- health condition of people (life expectancy, mortality level (death rate), duration and severity of diseases, physical and mental abilities of people, their health, quality and regularity of nutrition);

- $\quad$ area and arrangement of habitation, i.e. furnishings, convenience of planning, etc.;

- condition of education (duration and level of education, level of mastery of scientific knowledge, moral content and artistic level of literature, availability of libraries, museums, etc.);

- conditions and nature of work (work intensity and performance, compliance of work to personal inclinations of individual abilities of people; freedom of choice of profession and specialty; duration of the working day; the proportion of manual and automated labor; frequency and nature of occupational traumatism; microclimate in the team; material and social evaluation of labor);

- conditions of rest (rest period, availability of vacation houses homes and health resorts, culture and sports institutions);

- employment and the guarantee against unemployment;

- well-being of family life (appropriate behavior, high morality, a sense of life satisfaction and happiness).

It should be noted that the proposed method of determining the standard of living is focused more on social indicators than on economic ones.

Economic roll is in the classification of indicators of standards of living proposed by I. Domnina. Five groups of indicators are in the basis of the proposed system: population; labor market; standard of living; social security and social services; environment and public safety.

Each of the proposed groups is further detailed on a more specific set of indicators that reflect the particular socioeconomic problem.

The group of indicators that evaluate the demography of population is the most numerous one: the demographic situation in the region, health issues; education. The following indicators are used to estimate these parameters: life expectancy (years); mortality; infant mortality; the mortality from homicide and suicide; morbidity by sex, age; kinds of diseases, duration of diseases, the availability of hospital beds and the number of physicians; public expenditures of medical institutions; level of education of population; availability of pre-school institutions; expenditures on education, government payments to educational institutions.

\section{Conclusion}

The system of indicators of standard of living should include basic indicators of general economic development of person that characterize the welfare, health, education, science and culture of the society, the development of social 
infrastructure, demographic situation and social activity of population, the environmental component. Based on values of these parameters, it is possible to judge the levels of human potential development, the effectiveness and conditions of its reproduction.

Each indicator of standard of living consists of a group of indicators, including the integrating indicator; focusing on this indicator, it is possible to assess, control, even the levels of development and to improve the efficiency of definite territories and regions.

\section{Statements}

Considering the available methods of formation of the system of indicators of standard of living, we can conclude that all of them need to be clarified, updated, organized, as far as, on one hand, a lot of indicators are determined by the simplified scheme, for example, the integral HDI is estimated by only three factors (life expectancy, education and income per capita), on the other hand, they do not sufficiently take into account the specific character of the Russian economy with its diverse regional way of life, different levels of rating of territories concerning business and innovative climate, investment and financial attractiveness, information and institutional economic security, organizational diversity, technological, resource and environmental condition.

Therefore, we can come to conclusion that significant progress in the systematic methodology of construction of a model of quantitative and qualitative evaluation of standard of living will be needed.

Such models should include a unified nomenclature of indicators of standard of living that focuses on different levels of use - federal, regional and municipal.

\section{Sources}

Olenev N.N. Model vzaimodeystviya demograficheskih i ekonomicheskih protsessov (rozhdaemost, obrazovannost i blagosostoyanie). M.: VTs RAN, 2007.

$\checkmark$ poiskah novoy teorii: Kniga dlya chteniya po ekonomicheskoy teorii s problemnyimi situatsiyami. Pod. red. A.G.Gryaznovoy i N.N. Dumnoy. - M.: KNORUS, 2006.

Dyatlov S.A. Osnovyi teorii chelovecheskogo kapitala. - SPb.: SP6UEF,1994.

Bobkov V.N. Bednost, uroven i kachestvo zhizni: metodologiya analiza i mehanizmyi realizatsii // Uroven zhizni naseleniya regionov Rossii.-2005.-\#1.-S. 7-20.

Andrews F., Whitney S. Social Indicators of Well Being 11 American's perception of Life Quality. N.Y., Plenum Press, 1976. - XXI. - 455 p.

HFA "Health for all", Data Base for personal computer, WHO Regional office for Europe, Eurostat- PC, Copenhagen, 1996. - c. 8.

Byilevskiy P. Zhazhda razuma. Zametki s futurologicheskogo kongressa // "Zavtra" \# 13 (697) ot 28 marta 2007.

Gabdrakhmanov N.K. and Rozhko M.V. Positioning of Volga Federal District Regions by Demographic Situation Index // World Applied Sciences Journal, Volume 30 Number 6, 2014. - pp.792-795

Gabdrakhmanov, N.K. and V.A. Rubtzov, 2014. Geodemographic Polarization Processes: Municipal Level (The Case of the Kukmorsky Municipal District of the Republic of Tatarstan). World Applied Sciences Journal, 30(10): 1317-1320.

Varshavskiy A. Problemyi stabilizatsii ekonomiki Rossii. - M.: TsENI, 2008. - 45s.

Fahrutdinova L.R. Institutsionalnoe proektirovanie kachestva zhizni v rossiyskoy ekonomike // Segodnya i zavtra rossiyskoy ekonomiki. Nauchno-analiticheskiy sbornik \#43,2011

Rshashevskaya N.M. Kachestvennyiy potentsial naseleniya Rossii: vzglyad v XXI vek // Problemyi prognozirovaniya. 2001. - \#3. - S. 3541

Nekrasov V.I. Metodologicheskie osnovyi razvitiya hozyaystvennyih sistem v obespechenii ekonomicheskogo rosta. Ekaternburg. 2008.

Arnott Richard. Economic Theory and Housing//Handbook of Regional and Urban Economic. Vol.2/Ed.by Edwin S / Mills. N. Y.: ElsevierNorth Hollan Publishing, 1982.

Alston L. J., Eggertsson T., and North D. C. Empirical Studies in Institutional Change, Cambridge, Cambridge University Press, 1986.

Holl G. Subjective measure of life in Britain. -N.Y.: Oxford University Press, 1995.-132 p.

Garifova L.F., Kundakchyan R.M., Pratchenko O.V. Integral Estimate of Socio-Ecological-Economic Factors on the Quality of Life of Population of the Region // Mediterranean Journal of Social Sciences. - Vol.5, No12, (2014)-pp. 117 - 121. 